\title{
Purified egg protein supplementation has beneficial effects on body composition, metabolism and eating behavior and results in a more sustained weight loss than low fat diet
}

\author{
Jean-Frédéric Brun*, Emmanuelle Varlet-Marie, Thibault Fidani, Jacques Mercier and Eric Raynaud de Mauverger \\ University of Montpellier, INSERM, CNRS, CHU, Montpellier, France
}

\begin{abstract}
Background: An increasing body of literature emphasizes the interest of moderate enrichment in protein for treating obesity and its metabolic consequences. However, egg proteins that are known to have the highest biological value have not been studied in this context. We investigated in self-restricted obese individuals with low Protein Intake (PI) $\left(<0.7 \mathrm{~g} \cdot \mathrm{kg}^{-1} \cdot \mathrm{d}^{-1}\right)$ the effects of increasing PI up to $1.5 \mathrm{~g} \cdot \mathrm{kg}^{-1} \cdot \mathrm{d}^{-1}$ on body weight, body composition, eating behavior, Resting Metabolic Rate (RMR) and kidney function.

Randomized controlled trial over 2 months: Twelve subjects were given daily supplements of a formula of Purified high biological value Egg Protein (PEP) (Ovamine ${ }^{\circ}$ Nutreven laboratories, Paris) to achieve this level of PI while ten matched controls were given a simple Low-Fat High Protein Diet (LFHPD). Subjects were tested before and after 2 months. PEP resulted in increased PI $\left(1.39 \pm 0.07 \mathrm{vs} 0.65 \pm 0.07 \mathrm{~g}^{\mathrm{kg}} \mathrm{kg}^{-1} \cdot \mathrm{d}^{-1} p<0.01\right)$, higher percentage of protein $(+9.6 \%, p<0.01)$ and lower percentage of lipids $(-13,6 \%, p<0.01)$ in diet, while these values were not significantly modified with LFHPD. Analogic-numeric scales indicated that appetite increased under LFHPD and decreased under $\operatorname{PEP}(p=0.006)$ with a subjective feeling of eating less $(p<0.01)$, yet in both groups, total calculated energy intake was not decreased. Under PEP (but not LFHPD) there was a decrease in weight $(-1.97 \pm 0.5 \mathrm{~kg} p<0.01)$ and body mass index $(-0.74 \pm 0,18 \%, p<0.01)$ due to a decrease in fat mass only $(-3.2 \pm 1.3 \mathrm{~kg} p<0,05)$. There was in both groups a nonsignificant tendency to reduce RMR with no change in RER. Creatinine clearance increased by $10 \%$ under PEP (before: $149 \pm 19$; after: $162 \pm 22 \mathrm{ml} \cdot \mathrm{min}^{-1}, p=0.05$ ) but not under LFHPD. Microalbuminuria was unchanged.
\end{abstract}

Controlled follow-up trial over 18 months: 337 subjects divided into three matched groups followed over 18 months: no change in diet or lifestyle ( $\mathrm{n}=69)$; LFD $(\mathrm{n}=171)$, and PEP $(\mathrm{n}=97)$ targeting $1.2 \mathrm{~g} \cdot \mathrm{kg}^{-1} \cdot \mathrm{d}^{-1}$ protein with the same purified egg protein preparation of high biological value. In the group of control subjects $(n=58)$ there was a gradual weight increase up to $+8.58 \pm 0.56 \%$ of initial weight on the 18 th month, while subjects on low fat diet had lost $-5.55 \pm 1.31$ and those receiving moderate enrichment in protein had lost $-8.07 \pm 1.58$. The initial drop-out at 1 month is $-19 \%$ with low fat diet and $-15 \%$ with moderate enrichment in protein. After 6 months it is $-57 \%$ with low fat diet and $-47 \%$ with moderate enrichment in protein. During the first 6 months the curves of low-fat diet and protein supplementation are almost overlapped but after 8 months the difference becomes significant. At 18 months, subjects on low fat diet have lost $-5.95 \pm 1.82$ and those receiving moderate enrichment in protein have lost $-8.05 \pm 1.87(p=0.023)$. On the whole moderate enrichment in protein induces a weight loss $>10 \%$ in $18 \%$ of the subjects and a weight loss $>5-10$ in $22 \%$ of them. Visual analogic scales evidence in receiving egg protein a decrease in appetite $(p<0.01)$ and nibbling $(p<0.01)$ and an increase in satiety $(p<0.01)$.

Conclusion: This study is thus the first to demonstrate a fair efficacy of purified egg protein over the long term together with positive effects on body composition and eating behavior. PEP supplements are an easy means for increasing PI and reducing fat intake, while this goal remains difficult to achieve with simple diet. Despite no advice of caloric restriction and no increase in RMR, PEP induces a slight loss in body fat, with preservation of lean mass, and only marginal changes in glomerular filtration. Over 18 months it results in a significant weight loss, which is significantly more pronounced $(+38 \%)$ and continues over a longer period under PEP compared to LFD ( $p=0.003)$. In addition, we observe that the effect of this procedure on body weight is more pronounced in three categories of subjects: those with marked excess calorie intake, those with initial low protein intake, and those whose phase 2 insulin response is higher. Since egg proteins are the variety of proteins that possess the greatest biological value and have additional biological properties beneficial for cardiovascular and metabolic health, they are likely to represent a new promising tool for the management of obesity and metabolic syndrome. Further controlled studies are in progress to better assess this issue.

Abbreviations: BMR: Basal Metabolic Rate; HCLFD: High-Carbohydrate Low-Fat Diet; HPLFD: High-Protein Low-Fat Diet; PEP: formula of Purified high biological value Protein; REE: Resting Energy Expenditure.

\section{Introduction}

Diet and exercise remain the cornerstone of the management of obesity [1]. There has been by the past a lot of controversies about the best dietary approach [2]. Large recent studies have specified the effectiveness of the different diets that can be used in the long term: low in fats or sugars [3], Mediterranean [4], or moderately enriched in proteins (resulting in intakes of 1.2 to $1.6 \mathrm{~g} / \mathrm{kg} /$ day) [5]. It is generally observed that the latter allows a longer stabilization [6-7] although a recent study challenges this concept [8]. A meta-analysis concludes that it also induces a slightly greater weight loss [9].

${ }^{\star}$ Correspondence to: Jean-Frédéric Brun, University of Montpellier, INSERM, CNRS, Montpellier, France, E-mail: j-brun@chu-montpellier.fr

Key words: protein diet, protein intake, egg protein, body composition, eating behavior, microalbuminuria, glomerular filtration, obesity, weight loss, resting energy expenditure, insulin secretion

Received: September 28, 2018; Accepted: October 12, 2018; Published: October 18,2018 
Brun J (2018) Purified egg protein supplementation has beneficial effects on body composition, metabolism and eating behavior and results in a more sustained weight loss than low fat diet

Furthermore, these protein-enriched diets improve various components of the "metabolic syndrome" that usually accompanies excess adipose tissue [10-12].

Whether it helps to maintain muscle size and strength is generally also observed but there is not a full agreement about this [13].

On the whole, undoubtedly, this approach that was considered with caution fifteen years ago [14-15] appears to be a powerful tool against obesity, even more if it is accompanied by metabolic complications.

Actually, most of the research on diet-enriched proteins is based on studies using dietary protein enrichment, or milk protein supplementations [16]. However, among various sources of proteins available in human diet, egg proteins are classically presented as those with the highest biological value [17]. In fact, this source of proteins was long neglected due to the unfounded belief that egg content in cholesterol can increase the risk for cardiovascular diseases.

Recent literature rehabilitates the nutritional value of eggs, which were once feared to increase blood cholesterol and thus cardiovascular risk. Actually, large epidemiological studies show that egg consumption is not related to coronary heart disease incidence or mortality [18]. On the opposite, recent studies show that higher egg consumption is associated with a reduction in the odds for metabolic syndrome [19]. This may be related to the fact that egg proteins generate bioactive peptides with multiple biological effects, exerting anti-diabetic and anti-obesity effects in experimental animals [20].

We are not aware, however, of studies on humans supplemented with egg protein. This paper presents a series of studies conducted over the last years in our laboratory in order to assess the specific interest of them in human obesity. The rationale of the studies was that most obese subjects in our clinical practice were found to drastically reduce their meals, and thus their protein content, while nibbling at other moments of the day, and had thus a protein intake quite low $\left(<0.6 \mathrm{~g} \cdot \mathrm{kg}^{-1}\right.$.day $\left.{ }^{1}\right)$. On the other hand, the simple fact of restoring « normal regular meals » with a formula of a Purified high biological value Egg Protein (PEP) intake slightly above the recommended values; ie, approximately 1.2 to $1.4 \mathrm{~g} . \mathrm{kg}-1$.day -1 , and of course to reduce nibbling, seemed to restore the ability to lose weight. However, there was no scientific demonstration of this clinical observation. Given the fact that protein diets are supposed to both reduce appetite and increase energy wasting, we aimed at investigating the effects on resting energy expenditure and eating behaviour of a moderate enrichment in proteins in obese patients eating less than $0.7 \mathrm{~g} . \mathrm{kg}$-1.day 1 protein (in order to achieve 1.2 to 1.4 g.kg -1.day -1) without any other diet advice, compared to a high protein low fat advice. This randomized controlled study was then followed by a longitudinal controlled study of follow-up over 18 months to explain the unexpected finding of a spontaneous loss of fat mass over this short period.

\section{Subjects and Methods}

\section{Subjects}

All subjects included in the study were all overweight or obese (BMI $>25 \mathrm{~kg} / \mathrm{m}^{2}$ ). They were attending for weight loss at the outpatient's unit of the department of Endocrinology of the University Hospital of Montpellier. All were nonsmokers, and none had renal or hepatic disease, diabetes mellitus, heart disease, hypertension, or took prescription medications. Participants gave informed consent, and the study was conducted in accordance with the guidelines of the local ethics committee.

\section{Study over 2 months}

Subjects were stratified by age, gender, and BMI and randomly assigned to one of two experimental groups designated as a supplement of purified egg protein (PEP), and low-fat high protein diet (LFHPD). Subjects were tested before and after 2 months. Characteristics of the two groups are shown on Table 1.

In the PEP group subjects were given daily supplements of an original preparation of highly purified egg protein powder (OVAMINE*, 92 Bd Flandrin 75116, Paris, France) to achieve a level of protein intake of 1.2 to $1.4 \mathrm{~g} . \mathrm{kg}^{-1}$.day ${ }^{-1}$. Control subjects were prescribed a LFHPD. This LFHPD routinely used in our unit consists of a detailed advice to eat a breakfast comprising one or more protein meats, to reduce drastically fat in all meals, and to increase their protein intake in each meal in order to reach $1.2 \mathrm{~g} \mathrm{~kg}^{-1}$. $\mathrm{day}^{-1}$ to 1.4 , and to eat vegetables ad libitum. In this case subjects had to write on a special diary their daily meals for the first weeks of the diet and were seen again for a dietary advice 15 days after beginning of the diet and then each month. The dietary assessment was performed with a home-made software using the information collected on a standardized self-administered questionnaire [21-22]. In this protocol subjects of each group were tested before and after 2 months of diet.

Before and after the 2-months trial, the following measurements were performed: creatinine, serum insulin, plasma glucose, total cholesterol, LDL cholesterol, and triacylglycerols, HDL cholesterol. Total 24-h urine volumes were recorded, and an aliquot frozen $\left(45^{\circ} \mathrm{C}\right)$ until analysis of urine urea and creatinine (for the calculation of creatinine clearance) and microalbuminuria (by immunonephelemetry).

Testing comprised first a complete 24-h urine sampling, defined as all urine excreted after the first morning void through the initial next morning void. The following morning, subjects reported to the test site in a rested, fasted state (no light to heavy activity for $24 \mathrm{~h}$ and no food or beverage with the exception of water for $12 \mathrm{~h}$ ), and Resting Energy Expenditure (REE) was measured. Metabolic measurements were recorded using a respiratory mask and 2-way, nonrebreathing valve interfaced with analyzer CPX Medical Graphic Cardio 2, which includes a specific software for indirect calorimetry. Upon arrival at the laboratory, subjects were positioned in a bed and habituated to the open circuit spirometry metabolic analysis apparatus for $30 \mathrm{~min}$ in a temperature controlled $\left(25-27^{\circ} \mathrm{C}\right)$, darkened, quiet room.

The respiratory mask was then placed over the subject's face and carefully checked and sealed to prevent air leakage. Subjects were instructed to remain awake and not to move, fidget, or talk once the mask was in place. Following the 30 -min habituation period, REE

Table 1. comparison of the two subgroups, showing their correct matching for age, sex ratio, waist-to-hip ratio, and fatness

\begin{tabular}{|c|c|c|c|}
\hline & MEDP (n= 17) & $\begin{array}{c}\text { LFHPD diet (n } \\
\mathbf{= 1 2}\end{array}$ & comparison \\
\hline Gender (M/F) & 16-Jan & $03-\mathrm{Dec}$ & $\mathrm{ns}$ \\
\hline Age (years) & $51.7 \pm 2.8$ & $48.7 \pm 4.5$ & $\mathrm{~ns}$ \\
\hline Weight $(\mathrm{kg})$ & $92.3 \pm 3.8$ & $105 \pm 9.1$ & $\mathrm{~ns}$ \\
\hline Height (m) & $1.60 \pm 0.02$ & $1.65 \pm 0.02$ & $\mathrm{~ns}$ \\
\hline Waist-to-hip ratio & $086 \pm 002$ & $086 \pm 002$ & $\mathrm{~ns}$ \\
\hline BMI (kg/m²) & $34.9 \pm 1.3$ & $38.3 \pm 2.9$ & $\mathrm{~ns}$ \\
\hline$\%$ of fat & $46 \pm 2$ & $44 \pm 2.9$ & $\mathrm{~ns}$ \\
\hline $\begin{array}{c}\text { Ratio actual REE/ } \\
\text { predicted REE }\end{array}$ & $103.8 \pm 0.043$ & $111 \pm 0.067$ & $\mathrm{~ns}$ \\
\hline
\end{tabular}

MEDP: Formula of purified high biological value protein; LFHPD: Low Fat High Protein Diet; REE: Resting Energy Expenditure 
Brun J (2018) Purified egg protein supplementation has beneficial effects on body composition, metabolism and eating behavior and results in a more sustained weight loss than low fat diet

was estimated from a mean of 20 min of continuous gas sampling via indirect calorimetry. The CV for this procedure is $3 \%$. Gas analyzers were calibrated before and after each test by nitrogen and two primary standard gases accurate to $0.01 \%$. The pneumotachometer was calibrated using a 1-L syringe to deliver fixed volumes at variable flow rates. Immediately after REE testing, a baseline blood sample was collected.

At this time, subjects indicated on 7-point analogic-numeric -scale their perception of appetite (extremely hungry to extremely full), overall well-being, and of the volume of ingested food, how they generally had felt over the past week. Subjects were also asked to indicate how often they ate foods that were not provided as part of the study diet and how often they were unable to eat all of the foods provided as part of the study diet. At the completion of the 8-wk feeding trial, subjects repeated the same metabolic testing procedures as described above. Thus, REE measurements were performed exactly 8 weeks apart to control for possible confounding effects of the menstrual cycle on energy expenditure.

\section{Study over 18 months}

The results of the first study over 2 months and the unexpected weight loss although no alimentary restriction was prescribed prompted us to study in conditions of real life the effects over 18 months of such a supplementation in a population similar to that of the first study. The endpoint was crude weight loss, so that patients' weights were followed monthly. During the 3 first months of the study an analogic-numeric scale $[23,24]$ for hunger and satiety was also given to the patients in order to follow their eating behavior. This follow-up study has been presented in 2 congresses $[25,26]$. Three cohorts of patients are presented (Table 2): controls $(n=69)$; middle: low fat diet $(n=171)$; lower curve: moderate enrichment in protein $(n=97)$.

\section{Measurements}

Body composition, i.e., the measurement of fat mass and Fat Free Mass (FFM), was assessed with bioimpedance analysis with a six-terminal impedance plethysmograph BIACORPUS RX4000 BiacorpusRX4000, (Healthnesslink,79 8 avenue Jean-Jaurès 92130 Issy-les-Moulineaux, France) with data analysis with the software BodyComp8.4. This device measures total resistance of the body to an alternative electric current of $50 \mathrm{kHz}[27,28]$. Body fat mass, fat-free mass was calculated in each segment of the body according to manufacturer's database-derived disclosed equations, and total water with published equations using the classical cylindric model and Hanai's mixture theory [29].

\section{Breakfast test}

In a subset of subjects of study $\mathrm{N}^{\circ} 2$ a standardized breakfast test was employed. Subjects had been asked to fast for $12 \mathrm{~h}$ before commencement of the standardized breakfast that was composed of bread ( $80 \mathrm{~g})$, butter $(10 \mathrm{~g})$, jam (20 g), skimmed concentrated milk (80 $\mathrm{ml}$ ) (Gloria SA, Paris, France), sugar $(10 \mathrm{~g})$, and powder coffee (2.5 g). The breakfast thus comprised 2,070 kilojoules with $9.1 \%$ proteins, $27.5 \%$ lipids, and $63.4 \%$ carbohydrates. The average time for consuming the meal was $6 \mathrm{~min}$. Blood samples were taken twice before the meal and at 15, 30, 60, 90,120,150,180,210, 240 min following the start of the meal. This test, which has been designed to detect postprandial reactive hypoglycemia [30], elicits the same glycemic response as the conventional OGTT $[30,31]$.

All samples were analyzed for plasma insulin by radioimmunoassay (kit Bi Insulin IRMA; Schering CIS bio international, Gif-sur Yvette, France) and for plasma glucose content with an Olympus 2700 automate.

Insulin sensitivity was calculated with Caumo's "oral minimal model" [32] which is the application to OGTT or meal tests of the equations previously developed by R.N. Bergman for IVGTT [33]. It is based on the analysis of changes in plasma glucose and insulin concentration measured after the standardized breakfast. SI is given by the "oral minimal model" which is actually Bergman's one with simply another term called $\mathrm{Ra}{ }_{\text {OGTT }}$ added to the first equation. Model equations are thus:

$$
\begin{cases}\dot{G}(t)=-\left[\mathrm{S}_{\mathrm{G}}+X(t)\right] \cdot \mathrm{G}(t)+\mathrm{S}_{\mathrm{G}} \cdot \mathrm{G}_{\mathrm{b}}+\frac{\mathrm{R}_{\mathrm{ag}} \text { ogt }(\alpha, t)}{V} & \mathrm{G}(0)=\mathrm{G}_{\mathrm{b}} \\ \dot{X}(t)=-p_{2} \cdot \mathrm{X}(t)+p_{3} \cdot\left[\mathrm{I}(t)-\mathrm{I}_{\mathrm{b}}\right] & \mathrm{X}(0)=0\end{cases}
$$

Where $G$ is plasma glucose concentration, I is plasma insulin concentration, suffix " $\mathrm{b}$ " denotes basal values, $\mathrm{X}$ is insulin action on glucose production and disposal, $\mathrm{V}$ is distribution volume, and $\mathrm{S}_{\mathrm{G}^{\prime}}$ $\mathrm{p}_{2}$, and $\mathrm{p}_{3}$ are model parameters. Specially, $\mathrm{S}_{\mathrm{G}}$ is the fractional (i.e., per unit distribution volume) glucose effectiveness, which measures glucose ability per se to promote glucose disposal and inhibit glucose production; $\mathrm{p}_{2}$ is the rate constant describing the dynamics of insulin action; $\mathrm{p}_{3}$ is the parameter governing the magnitude of insulin action. Interestingly, these two equations can be simplified, allowing to calculate $\mathrm{S}_{\mathrm{I}}$ with a quite simple area under the curve formula:

$$
S_{\mathrm{IOGTT}}=\frac{f \cdot \mathrm{D}_{\mathrm{OGTT}} \cdot \frac{\mathrm{AUC}[\Delta G(t) / G(t)]}{\mathrm{AUC}[\Delta G(t)]}-\mathrm{GE} \cdot \mathrm{AUC}[\Delta G(t) / G(t)]}{\mathrm{AUC}[\Delta I(t)]}
$$

Where $\mathrm{G}$ is plasma glucose concentration, $\Delta \mathrm{G}$ and $\Delta \mathrm{I}$ are glucose and insulin concentrations above basal, respectively, AUC denotes the area under the curve; GE is glucose effectiveness termed above $\mathrm{p}_{1}$ or $\mathrm{S}_{\mathrm{G}}$ $\left(\mathrm{dl}_{\mathrm{kg}}{ }^{-1} \cdot \mathrm{min}^{-1}\right) ; \mathrm{D}_{\mathrm{OGTT}}$ is the dose of ingested glucose per unit of body weight $\left(\mathrm{mg}^{\mathrm{kg}} \mathrm{kg}^{-1}\right)$; and $f$ is the fraction of ingested glucose that actually appears in the systemic circulation. When glucose falls below basal, a slightly different formula needs to be used (we refer to Eq.7 in Caumo and al. [32]. Calculations of $\mathrm{S}_{\mathrm{I}}$ requires insertion of values for $\mathrm{S}_{\mathrm{G}}$ and $f$. Here we used the value of glucose effectiveness given by our previously validated formula $\left.\mathrm{S}_{\mathrm{G}}=2.921 \mathrm{e}^{-0.185(\mathrm{G}}{ }_{60}-\mathrm{G}\right)$. Besides, as in Caumo's paper, the value for $\mathrm{f}$ is set as $f=0.8$. This "oral minimal model" has been validated against glucose clamp, sophisticated tracer experiments and the classical IVGTT-based minimal model [31]. More recently we also reported its accuracy in type 2 diabetics [34].

\begin{tabular}{|c|c|c|c|c|c|c|c|c|}
\hline & Gender (F/M) & AGE (yr) & Weight $(\mathrm{kg})$ & Fat $(\%)$ & Fat (free mass $(\mathrm{kg})$ & $\begin{array}{c}\text { waist } \\
\text { circumference }(\mathrm{cm})\end{array}$ & $\begin{array}{l}\text { hip circumference } \\
(\mathrm{cm})\end{array}$ & BMI $\left(\mathrm{kg} / \mathrm{m}^{2}\right)$ \\
\hline CONTROLS & $64 \mathrm{~F} / 5 \mathrm{M}$ & 42.58 & 92.57 & 40.79 & 54.24 & 103,68 & 117.69 & 34.64 \\
\hline$(\mathrm{n}=69)$ & & $\pm 1.85^{* *}$ & \pm 11.05 & \pm 0.73 & \pm 1.16 & \pm 1.78 & \pm 1.57 & \pm 0.75 \\
\hline PROTEIN & $87 \mathrm{~F} / 10 \mathrm{M}$ & 47.48 & 92.85 & 40.66 & 54.43 & 105,19 & 116.46 & 34.25 \\
\hline$(n=97)$ & & \pm 1.85 & \pm 2.27 & \pm 0.50 & \pm 1.11 & \pm 1.55 & \pm 2.17 & \pm 0.86 \\
\hline LOW FAT & $140 \mathrm{~F} / 31 \mathrm{M}$ & 46.3 & 92.21 & 42.18 & 54.07 & 103,17 & 114.17 & 34.19 \\
\hline$(\mathrm{n}=171)$ & & \pm 1.26 & \pm 1.50 & \pm 0.52 & \pm 0.86 & \pm 1.28 & \pm 1.33 & \pm 0.50 \\
\hline
\end{tabular}

Table 2. Anthropometric and body composition parameters of study $N^{\circ} 2$ subjects (second study over years) (mean $\pm \mathrm{SEM}$ ) 
Brun J (2018) Purified egg protein supplementation has beneficial effects on body composition, metabolism and eating behavior and results in a more sustained weight loss than low fat diet

\section{Calculation of insulin secretion with C-peptide model}

Insulin secretion was also quantified from C-peptide kinetics as described by the well-known two-compartment model originally proposed by Eaton et al. [35] and further improved by van Cauter et al. [36] so that the model parameters were individually adjusted to the subject's anthropometric data.

$$
\begin{aligned}
& C \dot{P}_{1}(t)=-\left[k_{01}+k_{21}\right] C P_{1}(t)+k_{12} C P_{2}(t)+S R(t) C P_{1}(0)=0 \\
& C \dot{P}_{2}(t)=k_{21} C P_{1}(t)-k_{12} C P_{2}(t) C P_{2}(0)=0
\end{aligned}
$$

where the overdot indicates time derivative; $C P_{1}$ and $C P_{2}(\mathrm{nmol} / \mathrm{l})$ are C-peptide concentrations above basal in the accessible and peripheral compartments, respectively; $k_{\mathrm{ij}}\left(\mathrm{min}^{-1}\right)$ are C-peptide kinetic parameters, and insulin secretion rate $(S R)\left(\mathrm{pmol} \cdot \mathrm{l}^{-1} \cdot \mathrm{min}^{-1}\right)$ is pancreatic secretion rate above basal, entering the accessible compartment, and normalized by the volume of distribution of compartment 1 .

This $\beta$-cell response obtained with this classical calculation was then quantified with several classical parameters defined by the two most widely accepted models available in the literature $[37,38]$.

The most simplistic expression was maximal insulin secretion $\left(\mathrm{pMol} / \mathrm{min} / \mathrm{m}^{2}\right)$ ie the highest value of ISR during the test, and total insulin release over $210 \mathrm{~min}\left(\mathrm{pMol} / \mathrm{m}^{2}\right)$ which is calculated as the area under the curve. Another measurement of total insulin secretion global index of $\beta$-cell sensitivity to glucose, $\Phi\left(10^{9} \mathrm{~min}^{-1}\right)$, was calculated as follows, according to Breda [37] as the ratio between the AUC of total insulin secretion and the AUC of blood glucose concentration:

$$
\Phi=\frac{\int_{0}^{T}\left(S R(t)+S R_{b}\right) d t}{\int_{0}^{T}(G(t) d t}
$$

where $T(\mathrm{~min})$, is the time at which the system returns to steadystate conditions after the perturbation, is in this study the duration of the glucose-tolerance test covered by blood sampling.

$\beta$-cell sensitivity to glucose [38] which is approximately equivalent to the static sensitivity index $\Phi_{s}\left(10^{9} \mathrm{~min}^{-1}\right)$ [37] measures the effect of glucose on $\beta$-cell secretion at steady state. It is calculated as the slope $\left(\mathrm{pMol} / \mathrm{min} / \mathrm{mmol} / \mathrm{m}^{2}\right)$ of the relationship between SR and glucose concentration.

In a recent study we reported that these two indexes of second phase insulin response (Breda's $\Phi$ and Mari's $\beta$-cell sensitivity to glucose) are closely related to the magnitude of functional pancreatic islets mass [39].

Two indexes of first phase insulin secretion were measured. The derivative component, also called "rate sensitivity "or $\mathrm{k}_{1}$ ( $\mathrm{pMol.m}{ }^{-2}$. $\mathrm{mmol}^{-1}$ ) according to Mari [38] as the dynamic dependence of insulin secretion on the rate of change of glucose concentration. The dynamic sensitivity index $\Phi_{d}\left(10^{9}\right)$ is a measure of the stimulatory effect of the rate at which glucose increases upon the secretion of stored insulin. It is defined as the amount of insulin (per unit of C-peptide distribution volume) released in response to the maximum glucose concentration $\left(G_{\max }\right)$ achieved during the experiment, normalized by the glucose increase $G_{\max }-G_{\mathrm{b} \text {. This parameter }} \Phi_{\mathrm{D}}$ is calculated according to Breda [37].

$$
\Phi_{d}=\frac{\int_{G_{b}}^{G_{\operatorname{mix}}} k(G) d G}{G_{\max }-G_{b}}
$$

Basal insulin secretion $\left(\mathrm{pMol} / \mathrm{min} / \mathrm{m}^{2}\right)$ given by the C-peptide kinetics was also calculated, and also expressed as an index of basal $\beta$-cell sensitivity $\Phi_{\mathrm{b}}\left(10^{9} \mathrm{~min}^{-1}\right)$ as follows:

$$
\Phi_{b}=\frac{S R_{b}}{G_{b}}=\frac{k_{01} C P_{1 b}}{G_{b}}
$$

The potentiation factor ratio was also calculated according to Mari [38] as a time-varying factor, which is set to be a positive function of time and to average one during the experiment, encompassing all factors that may modulate insulin secretion (glucose and non-glucose substrates, gastro intestinal hormones, neuromodulation). It expresses a relative potentiation of the secretory response to glucose.

A disposition index was also calculated insulin secretion by insulin sensitivity, in analogy with Bergman et al. [40]. Actually, three different disposition indexes can be calculated after mixed-meal ingestion, by multiplying $\mathrm{k}_{1}$, $\beta$-cell sensitivity to glucose, and total insulin secretion $\Phi$ by SI.

\section{Statistics}

Data are reported as means SEM, and statistical analysis was with the Sigmastat package (Jandel Scientific, Erkrath, Germany). Comparisons were performed with two ways analysis of variance (ANOVA). Correlations were calculated on Microsoft EXCEL. Differences were considered significant at $p<0.05$.

\section{Results}

\section{Study 1, randomized trial over 2 months}

There were 16 drop-outs: 5 in the PEP group (all female), i.e. 5/22 or $22.7 \%$, versus 11 in the group LFHPD (1-man et 10 women i.e. 11/23 or $47.8 \%)$. The tendency towards a higher percentage of drop-out in the group LFHPD did not reach significance ( $p=0.11$ Fisher's exact test). Thus, from the total number of 45 subjects included in the study (22 assigned to receive PEP and 23 to receive LFHPD), 29 completed the protocol: 17 received PEP and 12 received LFHPD. Characteristics of all these subjects are given on Table 1 . It can be seen on this table that subjects are well matched for age, weight, height and percentage of fat.

While the dietary assessment did not evidence a reduction of food intake in either of the subgroups, Table 3 and Figure 1 show that the respective percentages of $\mathrm{CHO}$, lipid and proteins in patients' alimentation were not significantly changed on the average in the control group despite dietary prescription while in subjects that were given PEP the protein intake increased by $10.9 \%(p<0.01)$ with a parallel decrease of the lipid intake by $12.2 \%(p<0.01)$. The mean increase in daily intake of proteins in the PEP group was $0.73 \pm 0.09$ g. $\mathrm{kg}^{-1} / \mathrm{d}^{-1}(p<0.01)$ (Figure 2).

Analogic numeric scales rather show a decrease in appetite under PEP while appetite rather increases under dietary prescription $(-2.8 \pm$ 0.9 arbitrary units vs $+2.32 \pm 1.6 p=0.006)$. Patients that were given

Table 3. Effects of MEDP vs LFHPD diet on daily nutrient intake assessed by a standardized questionnaire before and after the two months of the protocol. Results show that there is no measurable change in quantifiable calorie intake, but that EPP increases by $100 \%$ protein intake, resulting in a higher percentage of protein and a lower percentage of fat. ${ }^{* * *} p<$ 0.01 (difference before vs after)

\begin{tabular}{|c|c|c|c|c|}
\hline & before MEDP & after MEDP & before LFHPD & after LFHPD \\
\hline $\mathrm{k} \mathrm{Cal} / 24 \mathrm{~h}$ & $1703.7 \pm 129.24$ & $1831.3 \pm 91$ & $1893.5 \pm 175.9$ & $\begin{array}{c}1973.36 \pm \\
245.87\end{array}$ \\
\hline$\% \mathrm{P}$ & $14.21 \pm 0.48$ & $26.7 \pm 2 * * *$ & $13.38 \pm 0.64$ & $14.6 \pm 0.7$ \\
\hline$\% \mathrm{~L}$ & $36.6 \pm 3.7$ & $26 \pm 2.7 * * *$ & $37.5 \pm 4.13$ & $36.2 \pm 4.2$ \\
\hline$\% \mathrm{G}$ & $47.6 \pm 4$ & $43 \pm 5.3$ & $43 \pm 2.7$ & $46 \pm 5.4$ \\
\hline $\begin{array}{c}\text { daily protein }(\mathrm{g} / \\
\mathrm{kg} / \mathrm{j})\end{array}$ & $0.65 \pm 0.07$ & $1.39 \pm 0.07 * * *$ & $0.67 \pm 0.09$ & $0.69 \pm 0.11$ \\
\hline
\end{tabular}




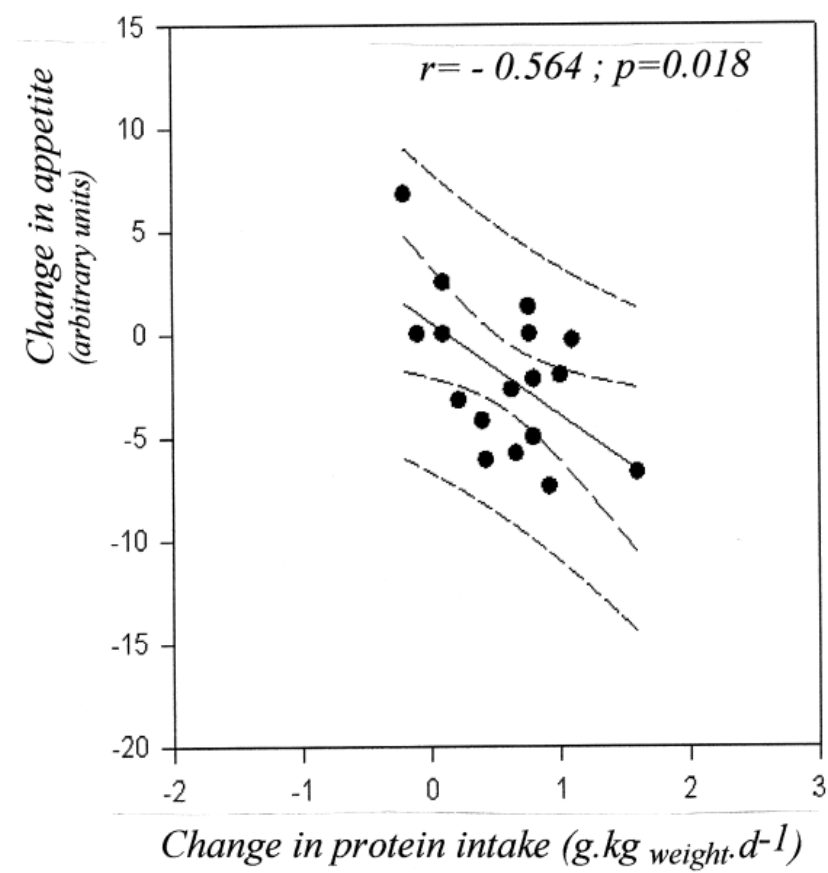

Figure 1. Negative correlation between change in appetite (analogic-numeric scale) and change in protein intake, showing that the feeling of hunger is decreased when protein intake increases

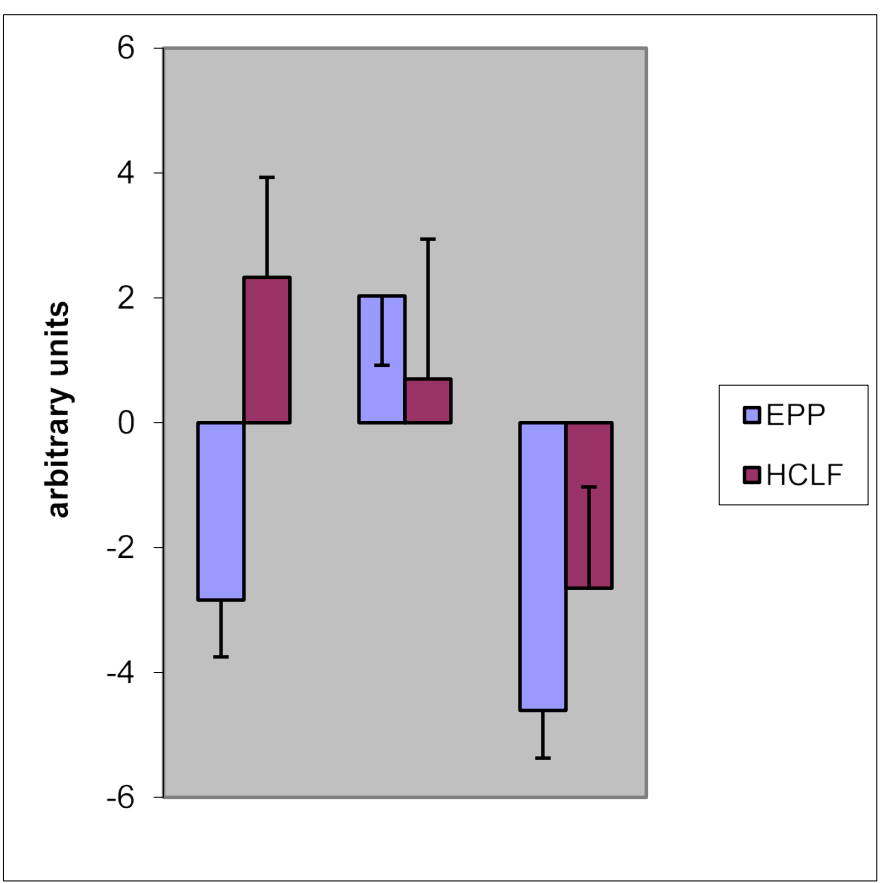

Figure 2. Effects of MEDP vs high CHO low fat diet (LFHPD) on modifications of appetite (left), well-being (middle) and food intake (right). All changes under MEDP: $p<0.001$

PEP mention the subjective feeling of eating less $(-4.61 \pm 0.75$ arbitrary units $p<0.01$ ).

Weight loss was not the primary endpoint of the study since no calorie restriction was prescribed. However, both diets resulted in weight loss. This loss was significant in the group that was given PEP, since in this group 14 subjects in a total group of 17 lose weight $(-1.87 \pm$ $0.6 \mathrm{~kg} ; p<0.01)$. In the group that was given diet alone this weight loss did not reach significance $(-1.3 \pm 1.4 \mathrm{~kg})$ while 9 subjects (from a total number of 11) lose weight. The body mass index exhibited a significant decrease in the group that was given PEP: $-0.67 \pm 0.21 \%(p<0.01)$. This decrease did not reach significance in the group that was given diet alone. ( $-0.43 \pm 0.5 \%, \mathrm{NS})$.

Waist circumference significantly decreased $(-3.05 \pm 1.22 \mathrm{~cm}, p<$ 0.05 in the group using PEP while that decrease was no longer found to be significant in the group that was given diet alone $(-0.29 \pm 1.8)$. Hip circumference did not change in any group. Waist-to-hip ratio was similar in both groups at the beginning and exhibited in both cases a non-significant trend to decrease.

There was a loss of fat mass $(-2.5 \pm 1.03 \mathrm{~kg}, p<0,05)$ in the group that was given PEP vs $-0.39 \pm 0.85$ under diet only (non-significant). By contrast the lean mass remained stable $(-0.11 \pm 0.7$ ns under PEP vs -1.8 \pm 1 under LFHPD, ns).

Urinary urea excretion exhibited a twofold increase in the group that was given PEP $(p<0.01)$, demonstrating thus an increase in protein catabolism that was not found in the group that was prescribed diet alone.

Resting energy expenditure (REE) exhibits in both groups a nonsignificant tendency to decrease $(-147 \pm 86 \mathrm{kcal} / 24 \mathrm{~h}$ under PEP vs $-143 \pm 67 \mathrm{kcal} / \mathrm{j}$ under diet alone). While these tendencies do not reach significance, they indicate that none of the dietary procedures used here increases the basal metabolic rate as hypothesized at the beginning of the study.

Creatinine clearance exhibits a very moderate increase with borderline significance $(+8.4 \%, p=0.05)$ in subjects that ware given PEP, since its values raise from $126 \pm 19$ up to $136 \pm 10 \mathrm{ml} / \mathrm{min}$ ). Creatinine clearance does not exhibit any change under diet alone. There is also a nonsignificant trend towards a rise in microalbuminuria (29.6 \pm 17 up to $59.4 \pm 38 \mu \mathrm{g} / \mathrm{min}$ under PEP) but this rise is not significant. Therefore, these data suggest a moderate increase in glomerular filtration but are on the edge of significance and cannot demonstrate it. If this rise were confirmed, it would be on the average of $10 \%$ and thus quite moderate.

The main statistical parameter explaining weight loss is the change in fat mass $(\mathrm{r}=0.440 ; p=0.017)$. On the whole fat free mass does not change.

This loss in fat mass is correlated to two modifications: the decrease in total daily calorie intake demonstrated by the dietary questionnaire $(r=0.392 ; p=0.05)$ and the subjective feeling of a decrease in total food ingestion $(r=0.446 p<0.05)$.

Correlations show that the increase in protein intake results in a decrease in lipid intake ( $r=0.733 ; p=0.0000209)$. This increase in protein intake decreases the perception of hunger $(r=0.564 ; p=0.0184)$ (Figure 2). It is associated with a feeling of eating less $(r=0.515 ; p=$ $0.0346)$. These two effects of the enrichment in proteins are correlated to each other: the decrease in appetite correlates with the feeling of eating less $(r=0.762 ; p=0.0002)$.

This feeling of eating less is weakly correlated to the decrease in fat mass (Figure 3$)(r=0.454 ; p=0.05)$ and to total weight loss $(r=0.454$; $p=0.05)$. Weight loss is correlated to the change in hip circumference $(r$ $=0.478 ; p=0.0087$ ).

Over this short period ( 2 months) that induced only a moderate weight loss there was no significant improvement of the biological parameters associated with overweight. Tendencies to decrease in fasting blood glucose, fasting insulin, and insulin resistance indexes 
Brun J (2018) Purified egg protein supplementation has beneficial effects on body composition, metabolism and eating behavior and results in a more sustained weight loss than low fat diet

calculated at fast (Table 4) do not reach significance. However, the decrease in BMI was associated on the analogic-numeric scales with an increase in the feeling of well-being $(r=0.604 ; p=0.0080)$. This increase in the feeling of well-being was correlated with the decrease in fat mass $(r=-0.4693 ; p=0.0494)$.

\section{Study 2, follow-up over 18 months of weight loss, compared to low fat diet}

The three cohorts of patients presented on Table 2 exhibited a very different profile of weight evolution, as evidenced by the significant differences detected by the ANOVA (Figure 4). In the group of control subjects there was a gradual weight increase up to $+8.58 \pm 0.56 \%$ of initial weight on the 18 th month, while subjects on low fat diet had lost $-5.55 \pm 1.31$ and those receiving moderate enrichment in protein had lost $-8.07 \pm 1.58$. Comparison of the three curves of weight change shows a highly significant difference $(p=0.003)$. However, during the first 6 months the curves of low-fat diet and protein supplementation are not significantly different and almost overlapped (ANOVA $p=0.117$, NS). After 8 months the difference becomes significant: subjects on low fat diet have lost $-5.95 \pm 1.82$ and those receiving moderate enrichment in protein have lost $-8.05 \pm 1.87(p=0.023)$. The difference between the two curves is significant at each point between 8 and 18 months. On the whole moderate enrichment in protein induces a weight loss $>10 \%$ in $18 \%$ of the subjects and a weight loss $>5-10$ in $22 \%$ of them (differences with the low-fat diet are not significant) (Table 5).

As usual in such studies there is a progressive decrease of the number of subjects remaining on diet. The initial drop-out at 1 month is $-19 \%$ with low fat diet and $-15 \%$ with moderate enrichment in protein. After 6 months it is $-57 \%$ with low fat diet and $-47 \%$ with moderate enrichment in protein.

As shown in Figure 4, questionnaires (visual analogic scales) evidence in the group receiving moderate enrichment in protein a decrease in appetite $(p<0.01)$ and nibbling $(p<0.01)$ and an increase in satiety $(p<0.01)$.

\section{Factors of success or failure of the diet}

In the whole sample of study 2 we can calculate the relationship between diet before the intervention and the effect of moderate enrichment in protein. Weight loss under EMP is correlated to initial fat stores $(r=-0.550 ; p<0.05)$, initial calorie intake $(r=-0.584 p<0.02)$ and initial protein intake $(r=0.310 p<0.05)$. Subjects initially eating $<$

Table 4. Comparison of the evolution in the two subgroups of the parameters studied

\begin{tabular}{|c|c|c|c|c|}
\hline & before MEDP & after MEDP & before LFHPD & after LFHPD \\
\hline Weight (kg) & $92.32 \pm 3.79$ & $90.45 \pm 3.78^{* * *}$ & $105.00 \pm 9.09$ & $103.64 \pm 8.84$ \\
\hline BMI $(\mathrm{kg} / \mathrm{m} 2)$ & $34.95 \pm 1.35$ & $34.28 \pm 1.43^{* * *}$ & $38.30 \pm 2.86$ & $37.86 \pm 2.87$ \\
\hline waist circumference & $102.82 \pm 3.17$ & $99.76 \pm 3.02 *$ & $110.04 \pm 6.33$ & $109.27 \pm 6.01$ \\
\hline hip circumference & $119.65 \pm 2.32$ & $118.74 \pm 2.84$ & $126.96 \pm 5.83$ & $125.50 \pm 6.21$ \\
\hline waist to hip ratio & $0.86 \pm 0.02$ & $0.84 \pm 0.02$ & $0.86 \pm 0.03$ & $0.86 \pm 0.02$ \\
\hline blood glucose $(\mathrm{mmol} / \mathrm{l})$ & $5.23 \pm 0.22$ & $5.02 \pm 0.22$ & $4.65 \pm 0.19$ & $5.34 \pm 0.28$ \\
\hline serum insulin $(\mu \mathrm{U} / \mathrm{ml})$ & $11.71 \pm 4.29$ & $9.45 \pm 1.97$ & $7.67 \pm 1.80$ & $8.00 \pm 1.79$ \\
\hline urinary urea $(\mathrm{g} / 24 \mathrm{~h})$ & $16.24 \pm 5.13$ & $30.99 \pm 4.04 * * *$ & $33.37 \pm 5.35$ & $39.81 \pm 7.12$ \\
\hline Plasma creatinine $(\mu \mathrm{Mol})$ & $72.92 \pm 2.99$ & $68.40 \pm 3.00$ & $69.77 \pm 2.95$ & $74.67 \pm 3.97$ \\
\hline créatinine clearance $(\mathrm{ml} / \mathrm{min})$ & $126.91 \pm 8.40$ & $136.46 \pm 10.65$ & $166.78 \pm 22.70$ & $173.36 \pm 25.17$ \\
\hline microalbuminuria $(\mu \mathrm{g} / \mathrm{min})$ & $18.86 \pm 8.97$ & $41.28 \pm 19.69$ & $7.96 \pm 3.49$ & $8.58 \pm 1.98$ \\
\hline $\mathrm{REE}(\mathrm{kCal} / 24 \mathrm{~h})$ & $1496.88 \pm 74.41$ & $1349.38 \pm 57.94$ & $1777.38 \pm 154.12$ & $1633.42 \pm 142.98$ \\
\hline RER & $0.82 \pm 0.02$ & $0.80 \pm 0.01$ & $0.87 \pm 0.02$ & $0.86 \pm 0.02$ \\
\hline lean body mass (kg) & $49.58 \pm 2.51$ & $49.47 \pm 2.56$ & $56.87 \pm 4.33$ & $55.09 \pm 4.34$ \\
\hline fat mass $(\mathrm{kg})$ & $42.89 \pm 3.23$ & $40.38 \pm 2.97^{*}$ & $48.20 \pm 6.11$ & $48.58 \pm 6.34$ \\
\hline total body water (1) & $41.26 \pm 2.18$ & $41.01 \pm 2.27$ & $46.42 \pm 3.91$ & $46.91 \pm 3.66$ \\
\hline$\%$ extracellular water & $39.88 \pm 1.00$ & $40.12 \pm 0.77$ & $42.09 \pm 1.39$ & $40.78 \pm 2.12$ \\
\hline
\end{tabular}

RER: Respiratory Exchange Ratio; * $\mathrm{p}<0.05 ; * * * \mathrm{p}<0.01$ (difference before vs after)

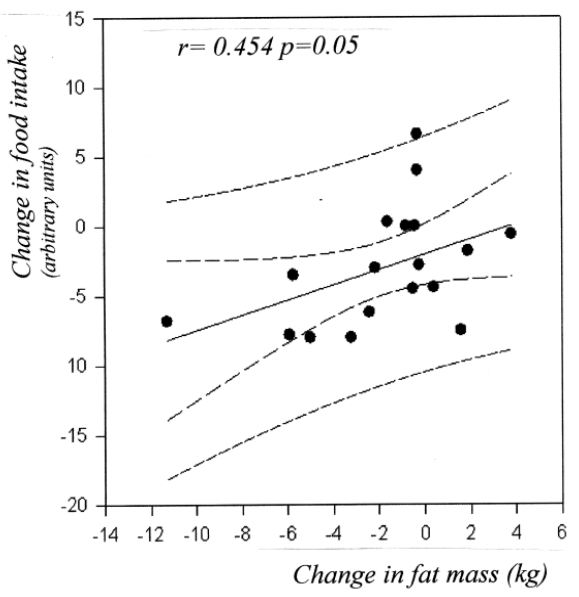

Figure 3. Correlation between change in food intake (analogic-numeric scale) and change in fat mass, showing that the feeling of eating less is associated with a decrease in fat mass 
Brun J (2018) Purified egg protein supplementation has beneficial effects on body composition, metabolism and eating behavior and results in a more sustained weight loss than low fat diet

$0.83 \mathrm{~g} / \mathrm{kg} / \mathrm{j}$ lose more weight $(-7.15 \pm 1.27 \%$ vs $-3.39 \pm 0.76 \% ; p<0.04)$ under EMP (Figure 5).

We also calculated in a subgroup of 39 subjects of study 2 the influence of glucoregulatory status. Subjects were divided into 2 groups, one group of 18 taking a moderate enrichment in protein as explained above, and another one of 21 taking the low-fat diet. Both groups were matched for age $(45.7 \pm 2.7$ vs $55.3 \pm 3.89)$, gender (ratio $\mathrm{M} / \mathrm{F}=0.20)$ and BMI ( $34.3 \pm 0.89$ vs $35.70 \pm 2.12)$. In both groups a breakfast test was performed at the beginning of the study. At 10 months subjects taking proteins had lost significantly more weight than those taking a low-fat diet $(-6,02 \pm 0,92$ vs $-2.56 \pm 0.76 \mathrm{~kg}, p<0.01$, ie, $-5.92 \pm 0.91 \%$ of initial body weight vs $-2.66 \pm 0.79 \%$; $p<0.02$ ). Patients exhibited at the beginning similar values of all parameters of insulin sensitivity and insulin secretion calculated with the models (data not shown). There was no correlation between insulin resistance, disposition index, or phase 1 insulin secretion and the extent of weight loss. By contrast (Figure 6) weight loss was correlated to pancreatic $\beta$-cell sensitivity in the subgroup of subjects taking proteins $(r=-0.557 ; p<0.01)$, and this relationship is no longer found in subjects taking the low-fat diet $(r=$ $-0.254 \mathrm{~ns}$ ). This finding indicates that an enhanced phase 2 of insulin secretion is a predictor of efficacy of a moderate enrichment in egg protein.

\section{Discussion}

This study shows that addition of PEP to the actual diet is an easy mean to achieve a "High-Protein, Low-Fat Diet", since it results in an increase in protein intake associated to a decrease in fat intake. It also evidences over a period of 2 months that this procedure is well tolerated, as evidenced by the increased feeling of well-being on the analogicnumeric scale, does not increase resting energy expenditure, and has only marginal effects on the glomerular function. Without any advice of caloric restriction, it results in a significant weight loss, consisting of

Table 5. Dietary habits of the subjects of study $\mathrm{N}^{\circ} 2($ mean \pm SEM)

\begin{tabular}{|c|c|c|c|c|c|}
\hline & $\mathbf{k C a l} / \mathbf{d a y}$ & $\mathbf{p r o t} \mathbf{g} / \mathbf{k g} / \mathbf{j}$ & $\mathbf{P \%}$ & $\mathbf{G} \%$ & $\mathbf{L \%}$ \\
\hline CONTROLS & 1890.02 & 0.73 & 16.27 & 56.22 & 27.42 \\
\hline$(\mathrm{n}=69)$ & \pm 90.40 & \pm 0.04 & \pm 0.72 & \pm 1.74 & \pm 1.49 \\
\hline PROTEIN & 1992.04 & 0.74 & 17.19 & 56.6 & 26.23 \\
\hline$(\mathrm{n}=97)$ & \pm 96.80 & \pm 0.03 & \pm 0.62 & \pm 1.53 & \pm 1.44 \\
\hline LOW FAT & 2073.91 & 0.82 & 18.04 & 55.06 & 27.04 \\
\hline$(\mathrm{n}=171)$ & \pm 61.05 & \pm 0.03 & \pm 0.47 & \pm 1.00 & \pm 0.84 \\
\hline
\end{tabular}

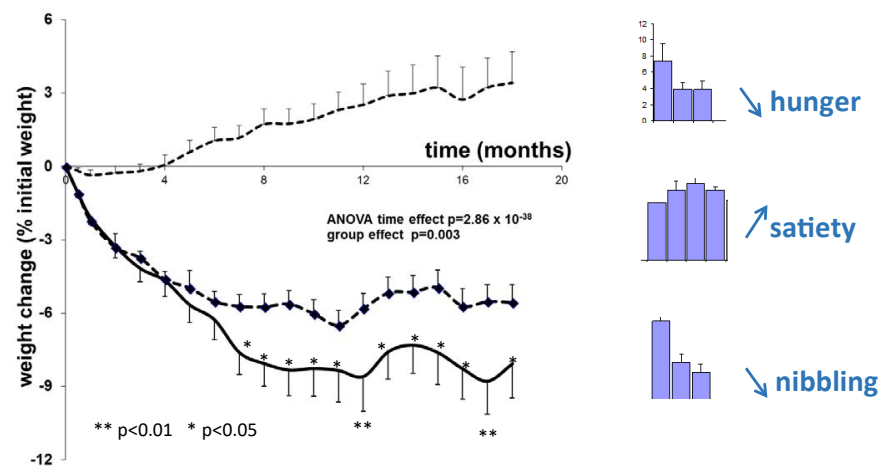

Figure 4. Weight loss (percentage of initial weight) over 18 months in the three groups of the study $\mathrm{N}^{\circ} 2$ : upper curve: controls $(\mathrm{n}=69)$; middle: low fat diet $(\mathrm{n}=171)$; lower curve: moderate enrichment in protein $(n=97)$. The difference among the three curves is highly significant. Black stars show the differences between low fat and protein which become significant after 8 months. On the right: scores of hunger, satiety and nibbling measured on the visual analogic scale

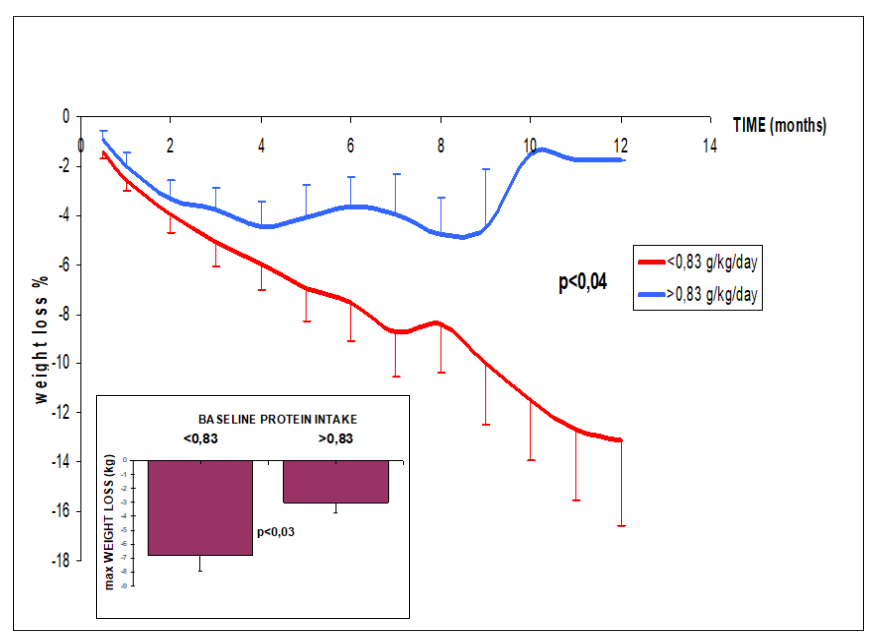

Figure 5. Weight loss (percentage of initial weight) over 12 months, showing better results in subjects initially restrained in protein intake $\left(<0.83 \mathrm{~g} \cdot \mathrm{kg}^{-1} \cdot \mathrm{d}^{-1}\right.$ eg the lower boundary of recommended intake)

\section{moderate enrichment in egg protein}

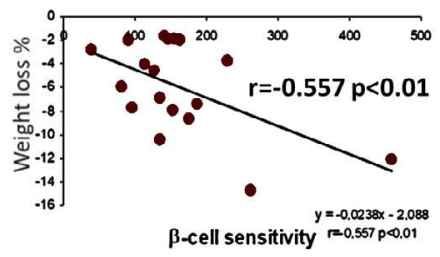

low-fat diet

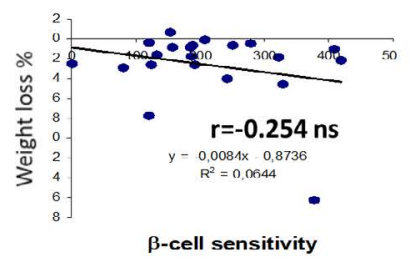

Figure 6. Correlations between $\beta$-cell sensitivity and weight loss in subjects taking moderate egg protein supplements (left) or low-fat diet (right). Weight loss was correlated to pancreatic $\beta$-cell sensitivity in the subgroup of subjects taking proteins $(r=-0.557 p<$ $0.01)$. This relationship is no longer found in subjects taking the low-fat $\operatorname{diet}(r=-0.254 \mathrm{~ns})$. This finding indicates that an enhanced phase 2 of insulin secretion is a predictor of efficacy of a moderate enrichment in egg protein but not a low-fat diet

an average decrease in fat mass of $2,5 \mathrm{~kg}$ without any decrease in fat-free mass over 2 months. The follow-up over 18 months shows that weight loss is significantly higher $(+38 \%)$ and continues over a longer period under PEP compared to LFD. In addition, we observe that the effect of this procedure on body weight is more pronounced in three categories of subjects: those with marked excess calorie intake, those with initial low protein intake, and those whose phase 2 insulin response is higher.

When we started this series of studies in the late nineties protein addition to diet was actually considered with caution $[14,15]$. However, the idea to reequilibrate protein intake around 1.2 g. $\mathrm{kg}^{-1} . \mathrm{day}^{-1}$ gained little by little more audience and our finding of the fair efficiency of this approach is in accordance with some recent literature. MEPDs have been reported to produce greater weight loss, increase loss of fat mass, minimize loss of lean mass, and improve dyslipidaemia (lower TAG and increased HDL-C) compared with commonly recommended hypocaloric (low fat or low $\mathrm{CHO}$ ) diets [12].

Even more, there is increasing evidence that the range of at least 1.2 to $1.6 \mathrm{~g}^{\mathrm{kg}} \mathrm{kg}^{-1}$. day ${ }^{-1}$ of high-quality protein is a more ideal target for achieving optimal health outcomes in adults [41]. Higher protein intakes may help prevent age-related sarcopenia, the loss of muscle mass and strength that predisposes older adults to frailty, disability, and loss of autonomy. Higher protein diets also improve satiety and lead to greater reductions in body weight and fat mass compared with standard 
Brun J (2018) Purified egg protein supplementation has beneficial effects on body composition, metabolism and eating behavior and results in a more sustained weight loss than low fat diet

protein diets and may therefore serve as a successful strategy to help prevent and/or treat obesity. Therefore, our approach is in line with current literature.

The main originality of our study is to employ egg protein rather than a preparation derived from milk. The fair efficacy of the preparation of egg proteins used in this series of studies is obvious. On the opposite, there has been some controversy as to whether purified protein supplements are more efficient for weight control than increasing the part of food containing protein in diet remains controversial $[42,43]$ but protein supplements in those studies are most of the time derived from dairy products.

It is beyond doubt than dairy products are an important component of a well-balanced diet and a healthy lifestyle for metabolic health [44]. Even more, a recent study shows that increased dairy intake as part of energy restricted diets resulted in greater loss in body weight and fat mass while attenuating lean mass loss in 18-50-year-old adults and are thus a nutritional tool against obesity [45]. However, whether wheyderived protein supplements are a good tool for losing weight over the long term remains controversial.

Since egg protein has a higher biological value than dairy protein [17], an enhanced efficacy can theoretically be expected. Our study was not designed for detecting such a difference but at least it clearly demonstrates that adding a purified egg protein preparation with the goal to reach the upper range of physiological requirements is more efficient than a diet restricted in fat for losing weight and maintaining it over more than 18 months.

There are other interests of egg protein in such a context. In complete disagreement with the classical status that eggs can be deleterious for health because of their content in cholesterol, current large epidemiological studies show that egg consumption is not related to coronary heart disease incidence or mortality [18]. Even more, recent studies show that higher egg consumption is associated with a reduction in the odds for metabolic syndrome [19]. This may be related to the fact that egg proteins generate bioactive peptides with multiple biological effects, exerting anti-diabetic and anti-obesity effects in experimental animals [20].

Egg white mainly consists of water (88\%) and protein (11\%) and is lacking in lipids. Among these proteins, Ovalbumin and Ovomucin are good sources of amino acids. Ovotransferrin is also a fair source of iron. Hydrolysis products of several egg proteins such as Ovotransferrin, Ovomucin and Lysozyme have also remarkable immune-regulatory properties that are studied in animal models of cancer or inflammatory diseases [46] and can thus be expected to have beneficial effects on the low grade inflammation that is found in most cases of obesity [47] and whose pathogenetic role in insulin resistance is a matter of debate [48].

Therefore, our paper provides a good evidence that egg protein is an interesting tool in obesity, with a weight-lowering efficacy which is at least not inferior to other protein supplements. The specific beneficial properties of egg proteins reminded above suggest that purified egg protein can be expected to be a useful aid for treating obesity and metabolic syndrome. A multicentric randomized study to better demonstrate this is planned for the next years.

In this study, over people still under diet à 6 mo grossly there are $45 \%$ responders (> 5\% weight loss) and 55\% nonresponders. Two categories of "responders" are identified: (1) self-restricted low protein eaters; (2) 'overeater' 'patients with initially high caloric intake. A good response is also favourited by increased insulin second phase response to glucose, i.e. hyperinsulinism.
The effect on self-restricted low protein eaters is consistent with Bosse and Dixon's "theory of protein spread" which assumes that providing a sufficient deviation from habitual protein intake is a key factor in determining the success of protein supplements in weight management interventions [49].

The effect on 'overeater' 'patients with initially high caloric intake is logic, if one keeps in mind the effects of proteins on the feeling of satiation, which may help to decrease the orexigenic drive, as clearly evidenced in our two studies. In addition, it is in line with Simpson and Raubenheimer's "protein leverage theory" [50] which predicts that humans adjust their food intake to maintain a relatively constant dietary protein intake, so that diets with low protein density will have higher energy intakes, while diets with higher protein density will have lower energy intakes.

The effect on patients whose phase 2 of insulin secretion is increased is also logic, since insulin increases hunger and fat storage. Presumably, adding more protein will reduce hypersecretion of insulin and thus decrease an obesogenic factor.

These three profiles of "good responders to moderate protein increase" may explain the overall powerful effect on a general nonselected population of obese subjects, since all three put together represent a significant proportion of an obese population.

In study number 1 we show that PEP does not increase resting metabolic rate. However other studies show that it increases diet induced thermogenesis $[12,51]$. Clearly PEP has a regulatory effect on eating behaviour (decrease in appetite and nibbling) which is likely to explain most of its efficiency in overeaters. On the other hand, it seems that restoring a protein intake $>0.83 \mathrm{~g} \cdot \mathrm{kg}^{-1} \cdot \mathrm{day}^{-1}$ in self-restricted patients unlocks the slimming process. The most likely explanations are an increased diet induced thermogenesis and a correction of nibbling that is usually found in situations of self-calorie and protein restriction.

Whether this simple increase in protein may induce alterations in energy balance sufficient for a weight loss is a usual statement of promotors of commercial protein diets but remains poorly documented in scientific literature.

This study, which was not designed to analyse the effects of this dietary procedure on lipid and carbohydrate metabolism, is unable to evidence a statistically significant improvement in these parameters as evidenced by Johnston [51] after a high-protein diet low in fat. However, there is a tendency suggesting that on a higher sample and/or on a longer duration these improvements would probably be observed. By contrast, we evidence a good tolerance of this procedure (as shown by the analogic-numeric scale of well-being) and a weight-reducing effect.

This weight-reducing effect is found despite no advice to restrain food intake. The calculation of daily food intake is unable to evidence a significant decrease in quantifiable nutriments. However, on the analogic-numeric scale subjects quote a decrease in food intake, which seems thus to mostly affect non-quantified food (ie, nibbling). Thus, one of the probable mechanisms of this weight reduction was a decrease in food intake outside of the main meals.

However, we addressed in this study another hypothesis, which frequently appears in the commercial documents on high protein diet: a possible effect of increased protein intake on energy expenditure. Actually, it is clear that neither of the two diets studied here increases resting energy expenditure. On the other way about, there seems to be, as usual in all weight-reduction procedures, a decrease in resting energy expenditure, which is not significant in this study but could perhaps be 
evidenced on a larger sample. Thus, the addition of protein powder to the diet does not increase resting energy expenditure.

Another kind of thermic effect of protein powder could be that it increases postprandial thermogenesis, which usually represents $10 \%$ of the total energy expenditure [52] but can be increased by $100 \%$ after protein addition to the meal [51]. This part of thermogenesis which is difficult to adequately quantify was not assessed here. It does not seem to play a great part in the regulation of body weight and its possible involvement in the pathogenesis of obesity remains undemonstrated [53]. It could be reasonably hypothesized that PEP addition to the daily food increases this thermogenesis to some extent [51], but this mechanism is likely to be of minor importance for explaining the decrease in body weight observed in our study.

On the whole, the main mechanism of the weight loss seems to be a reduction in food intake, since the classically described anorexigenic effect of protein intake [54] has been largely confirmed during recent studies [55]. Since raw calculations of the 24-h food intake are unable to evidence a decrease in total calorie ingestion, it seems logic to assume that this decrease (described on the analogic-numeric scale) mostly affects food taken outside of the meals.

Another interesting effect of this protein supply is that it increases the percentage of protein with a parallel decrease in the percentage of ingested fat. Since in usual alimentation protein is most often accompanied by fat, this specific effect of pure protein supplements needs to be emphasized. It is likely that the weight loss induced by this protein supplement is mostly a result of these two effects: reduced nibbling and decreased fat intake. The mechanisms of this change in eating behaviour has not been addressed in this study but is likely to be related to PEP-related alterations in amino-acid balance resulting in modifications in central nervous system neurotransmitter release.

Obviously, it is impossible to extrapolate from such a study the longterm effects of such a diet. It should be reminded that in children excess protein intake has been suggested to result in further obesity [56,57]. Long term studies are needed to rule out such an effect in adults. Other expected side-effects of high protein diets need to be carefully investigated. Among them, the deleterious effects of high protein diet on kidney and liver functions remain the most serious concern. In rats, such diets have been reported to increase the size of these two organs [58-61]. In our study, the total quantities of protein were not very far from the usual range and are even below those found in large parts of the western populations. While a very slight increase in glomerular clearance can be evidenced, we remain very far from pathologic levels. In addition, urinary albumin excretion is not significantly increased.

Other potential effects of excess protein intake have been described: insulin resistance [58,59], impaired cortisol secretion [62], higher calcium urinary loss $[63,64]$, increased oxidative stress [65], alterations in detoxification enzymes [66]. These issues have not been addressed in this study, but current literature seems to minimize their importance even with markedly higher protein quantities [12]. Our data on insulin and glucose do not significantly evidence over a so short period any change in glucoregulation but the tendency seems to be rather to improvement than to worsening. We think that results close from those observed by Johnston [51] could be expected if such a diet is prolonged over a longer period, since the overall effect of this protein adjunction is to induce a low-fat high protein diet.

Our study has limitations and strengths. While the first part of the paper presents a randomized controlled study designed to include the appropriate number of subjects to avoid type- 2 errors, the second part is a controlled non-randomized study presenting matched cohorts separately assigned to a group. The control group with no diet and which exhibits a gradual weight gain is actually a sample of subjects that still wanted to be followed but were unable to start a weight reducing procedure, expecting to do so in a next future. The evolution of weight in this control group is similar to that reported by Slentz and coworkers in the STRRIDE study [67], which is $+1.0 \pm 2.7 \%$ of initial body weight. In our series it is at 8 months $1.85 \pm 0.61 \%$. Interestingly, in this group weight gain increases after time: $8,58 \pm 0,56 \%$ at 18 months. This finding clearly shows that continued physical inactivity results in progressive weight gain, as pointed out by the authors of STRRIDE [67]. The low-fat diet group in study 2 is a cohort of obese subjects routinely treated by diet only in our unit. This low-fat, restricted-calorie diet closely fits with the guidelines of the American Heart Association [68]. The weight-reducing effect of this procedure at 18 months $(-5.55$ $\pm 1,31)$ is close to that reported for low fat diet in the controlled trial of Shai [4] (3.3 kg, grossly 4\%). Therefore, the two matched comparison groups provide a very realistic picture of the effects of no action or lowfat diet in obese individuals in conditions of true life, consistent with the findings of the literature. Comparison of these two groups with our egg protein supplemented group is thus fully relevant.

However, there is another concern which is the issue of attrtion. Obviously, a significant number of patients were lost of view during this period. Over the first-year subjects enrolled in the two programs (protein or low fat) had the same rate of drop outs, e.g. almost $75 \%$, which was also the number of control patients (adhering to none of the programs) that were lost of view. In obesity trials, attrition rates can be evaluated on the average at 50\% [69]. Actually, a wide range of percentages (from 10 to $80 \%$ ) can be found in the literature [70]. Clearly, attrition should be considered as a major cause of treatment failure in the field of obesity. In the DIRECT study [4], the reported attrition rate is much lower, since adherence to diet was $95.4 \%$ at 1 year and $84.6 \%$ at 2 years, but the conditions of this important trial are not those of usual obesity managing, and the follow-up of subjects is much closer.

The strengths of the paper are the randomized design of study 1 and, for study 2, the fact that it represents a sample of subjects in conditions of 'true life', continuing their training over 18 months or more with on the average persisting weight-reducing effects. A multicentric randomized control trial is currently being planned to confirm this finding with a more controlled design. Another strength of study 2 is the use of a sophisticated analysis of glucoregulation which allows us to analyze the two phases of insulin release in response to glucose.

\section{Conclusions}

Therefore, on the whole, our study shows that a moderate enrichment in purified egg protein of daily alimentation in obese subjects eating low protein levels induces a weight loss which is well tolerated and does not decrease the lean body mass. Effects on kidney function seem quite moderate. This weight loss is likely to be mostly explained by a reduction in nibbling and a decrease in fat intake. It continues over at least 18 months and has a significantly stronger and more prolonged effect than a low-fat diet. The best effects are found in subjects initially restricted in proteins, in subjects ingesting a high amount of calories, and in hyperinsulinemic subjects. Therefore, adding PEP to an individual's diet is an easy means to induce a low fat, moderately hypocaloric diet; and to prevent nibbling. This very simple procedure results in a prolonged weight loss over 18 months and is more efficient than a conventional low-fat diet. Furthermore, 
Brun J (2018) Purified egg protein supplementation has beneficial effects on body composition, metabolism and eating behavior and results in a more sustained weight loss than low fat diet

taking into account the higher biological value of egg proteins and the recent literature suggesting that egg proteins have additional beneficial effects on metabolism and inflammation, this study leads to think that such a preparation of highly purified egg protein is a promising tool for treating obesity and metabolic syndrome. For this reason, a multicentric randomized study to further assess this finding is planned over the next years.

\section{Competing interests}

We are grateful to Nutreven laboratories who provided free samples of PEP for this study and gave us the opportunity to present these results in 5 congresses. Otherwise there was no disclosure of interest.

\section{References}

1. Manore MM, Larson-Meyer DE, Lindsay AR, Hongu N, Houtkooper L (2017) Dynamic Energy Balance: An Integrated Framework for Discussing Diet and Physical Activity in Obesity Prevention-Is it More than Eating Less and Exercising More? Nutrients 9: 905. [Crossref]

2. Dubnov-Raz G, Berry EM (2010) Dietary approaches to obesity. Mt Sinai J Med 77: 488-498. [Crossref]

3. Strychar I (2006) Diet in the management of weight loss. CMAJ 174: 56-63. [Crossref]

4. Shai I, Schwarzfuchs D, Henkin Y, Shahar DR, Witkow S, et al. (2008) Weight loss with a low-carbohydrate, Mediterranean, or low-fat diet. N Engl J Med 359: 229-241. [Crossref]

5. Aller EE, Larsen TM, Claus H, Lindroos AK, Kafatos A, et al. (22014) Weight loss maintenance in overweight subjects on ad libitum diets with high or low protein content and glycemic index: the DIOGENES trial 12-month results. Int J Obes (Lond) 38: 1511-1517. [Crossref]

6. Clifton PM, Keogh JB, Noakes M (2008) Long-term effects of a high-protein weightloss diet. Am J Clin Nutr 87: 23-29. [Crossref]

7. Soenen S, Martens EA, Hochstenbach-Waelen A, Lemmens SG, Westerterp-Plantenga MS (2013) Normal protein intake is required for body weight loss and weight maintenance, and elevated protein intake for additional preservation of resting energy expenditure and fat free mass. $J$ Nutr 143: 591-596. [Crossref]

8. Kjolbaek L, Sorensen LB, Sondertoft NB, Rasmussen CK, Westerterp-Plantenga MS (2017) Protein supplements after weight loss do not improve weight maintenance compared with recommended dietary protein intake despite beneficial effects on appetite sensation and energy expenditure: a randomized, controlled, double-blinded trial. Am J Clin Nutr 106: 684-697. [Crossref]

9. Wycherley TP, Moran LJ, Clifton PM, Noakes M, Brinkworth GD (2012) Effects of energy-restricted high-protein, low-fat compared with standard-protein, low-fat diets: a meta-analysis of randomized controlled trials. Am J Clin Nutr 96: 1281-1298.

10. Fekete AA, Giromini C, Chatzidiakou Y, Givens DI, Lovegrove JA (2016) Whey protein lowers blood pressure and improves endothelial function and lipid biomarkers in adults with prehypertension and mild hypertension: results from the chronic Whey2Go randomized controlled trial. Am J Clin Nutr 104: 1534-1544. [Crossref]

11. Dong JY, Zhang ZL, Wang PY, Qin LQ (2013) Effects of high-protein diets on body weight, glycaemic control, blood lipids and blood pressure in type 2 diabetes: metaanalysis of randomised controlled trials. Br J Nutr 110: 781-789. [Crossref]

12. Drummen M, Tischmann L, Gatta-Cherifi B, Adam T, Westerterp-Plantenga M (2018) Dietary Protein and Energy Balance in Relation to Obesity and Co-morbidities. Front Endocrinol (Lausanne) 9: 443. [Crossref]

13. Smith GI, Commean PK, Reeds DN, Klein S, Mittendorfer B (2018) Effect of Protein Supplementation During Diet-Induced Weight Loss on Muscle Mass and Strength: A Randomized Controlled Study. Obesity (Silver Spring) 26: 854-861. [Crossref]

14. St Jeor ST, Howard BV, Prewitt TE, Bovee V, Bazzarre T, et al. (2001) Dietary protein and weight reduction: a statement for healthcare professionals from the Nutrition Committee of the Council on Nutrition, Physical Activity, and Metabolism of the American Heart Association. Circulation 104: 1869-1874. [Crossref]

15. Manninen AH (2004) A statement of the american heart association nutrition committee on dietary protein and weight reduction: a rigorous rebuttal. Metab Syndr Relat Disord 2: 9-13. [Crossref]

16. Sousa GT, Lira FS, Rosa JC, de Oliveira EP, Oyama LM, et al. (2012) Dietary whey protein lessens several risk factors for metabolic diseases: a review. Lipids Health Dis 11: 67. [Crossref]
17. Song WO, Kerver JM (2000) Nutritional contribution of eggs to American diets. J Am Coll Nutr 19: 556S-562S. [Crossref]

18. Fernandez ML (2006) Dietary cholesterol provided by eggs and plasma lipoproteins in healthy populations. Curr Opin Clin Nutr Metab Care 9: 8-12. [Crossref]

19. Shin S, Lee HW, Kim CE, Lim J, Lee JK, et al. (2017) Egg Consumption and Risk of Metabolic Syndrome in Korean Adults: Results from the Health Examinees Study. Nutrients 9. [Crossref]

20. de Campos Zani SC, Wu J, Chan C B (2018) Egg and Soy-Derived Peptides and Hydrolysates: A Review of Their Physiological Actions against Diabetes and Obesity. Nutrients 10. [Crossref]

21. Monnier L, Colette C, Percheron C, Pham TC, Sauvanet JP, et al. (2001) Évaluation alimentaire en pratique courante : comment concilier rapidité, simplicité et fiabilité ? Diabetes \& Metabolism 27: 388-395.

22. Manetta J, Khaled S, Bouix D, Krechiem K, Brun JF, et al. (1997) Evaluation d'un auto questionnaire alimentaire court par comparaison avec un entretien diététique chez des sujets sportifs et sédentaires. Science \& Sports 12: 210-213.

23. Guiraudou M, ChérifA, Richou M, Fidani T, Romain AJ, et al. (2018) Effects Over $24 \mathrm{Hr}$ of Exercise Targeted on Lipid versus Carbohydrate Oxidation on Eating Behaviour in Normal Weight Volunteers. Int J Sports Sci Med 2: 031-035.

24. M Guiraudou, AJ Romain, M Mawunu, K Bedjih, C Fedou, JF Brun (2016) Effets chroniques de l'exercice ciblé au niveau d'oxydation maximale des lipides (LIPOXmax) sur le comportement alimentaire de sujets obèses sédentaires. Science \& Sports 31: 1318.

25. Brun JF, Fedou C, Raynaud de Mauverger E (2010) Effects of a moderate increase in protein intake (egg protein powder) on energy expenditure, kidney function, eating behaviour and weight loss in self-restricted obese patients.11th International Congress on Obesity, Stockholm 11-15th July 2010. Obesity Reviews 11: 238-239.

26. Brun JF, Fedou C, Raynaud de Mauverger E (2014) Efficacité amaigrissante à 18 mois ans d'un enrichissement modéré en protéines comparé à un régime hypolipidique. Journées Francophones de 28: suppl 1 pS141.

27. Brun JF, Guiraudou M, Mardemootoo C, Traoré A, Raingeard I, et al. (2013) Validation de la mesure segmentaire de la composition corporelle en comparaison avec la DEXA: Intérêt de la mesure de la masse grasse tronculaire. Science \& Sports 28: 158-162.

28. Guiraudou M, Maimoun L, Dumas JM, Julia M, Raingeard I, et al. (2015) Composition corporelle mesuree par241 imp'edancem'etrie segmentaire (BIAS) et performance de sprint chez les rugbymen/Body composition measured by bioimpedance segmental (BIAS) analysis and sprint performance in rugby players, Science \& Sports 298: 302.

29. Jaffrin MY, Morel H (2008) Body fluid volumes measurements by impedance: A review of bioimpedance spectroscopy (BIS) and bioimpedance analysis (BIA) methods. Med Eng Phys 30: 1257-1269. [Croosref]

30. Brun JF, Fedou C, Bouix O, Raynaud E, Orsetti A (1995) Evaluation of a standardized hyperglucidic breakfast test in postprandial reactive hypoglycaemia. Diabetologia 38: 494-501. [Crossref]

31. Aloulou I, Brun JF, Mercier J (2006) Evaluation of insulin sensitivity and glucose effectiveness during a standardized breakfast test: comparison with the minimal mode analysis of an intravenous glucose tolerance test. Metabolism 55: 676-690. [Crossref]

32. Caumo A Bergman RN, Cobelli C (2000) Insulin sensitivity from meal tolerance tests in normal subjects: a minimal model index. J Clin Endocrinol Metab 85: 4396-4402. [Crossref]

33. Bergman RN, Ider YZ, Bowden CR, Cobelli C (1979) Quantitative estimation of insulin sensitivity. Am J Physiol 236: E667-677. [Crossref]

34. Brun JF, Ghanassia E, Fedou C, Bordenave S, Raynaud de Mauverger E, et al. (2013) Assessment of insulin sensitivity SI and glucose effectiveness SG from a standardized hyperglucidic breakfast test in type 2 diabetics exhibiting various levels of insulin resistance. Acta Diabetol 50: 143-145. [Crossref]

35. Eaton RP, Allen RC, Schade DS, Erickson KM, Standefer J (1980) Prehepatic insulin production in man: kinetic analysis using peripheral connecting peptide behavior. $J$ Clin Endocrinol Metab 51: 520-528. [Crossref]

36. Van Cauter E, Mestrez F, Sturis J, Polonsky KS (1992) Estimation of insulin secretion rates from $\mathrm{C}$-peptide levels. Comparison of individual and standard kinetic parameters for C-peptide clearance. Diabetes 41: 368-377. [Crossref]

37. Breda E, Cavaghan MK, Toffolo G, Polonsky KS, Cobelli C (2001) Oral glucose tolerance test minimal model indexes of beta-cell function and insulin sensitivity. Diabetes 50: 150-158. [Crossref] 
Brun J (2018) Purified egg protein supplementation has beneficial effects on body composition, metabolism and eating behavior and results in a more sustained weight loss than low fat diet

38. Mari A, Schmitz O, Gastaldelli A, Oestergaard T, Nyholm B, et al. (2002) Meal and oral glucose tests for assessment of $\beta$-cell function: modeling analysis in normal subjects. Am J Physiol Endocrinol Metab 283: E1159-E1166. [Crossref]

39. Villard O, Brun JF, Bories L, Molinari N, Benhamou PY, et al. (2018) The second phase of insulin secretion in non-diabetic islet-grafted recipients is altered and can predict graft outcome. J Clin Endocrinol Metab 103: 1310-1319.

40. Bergman RN, Hope ID, Yang YJ, Watanabe RM, Meador MA, et al. (1989) Assessment of insulin sensitivity in vivo: a critical review. Diabetes Metab Rev 5: 411-429. [Crossref]

41. Phillips SM, Chevalier S, Leidy HJ (2016) Protein "requirements" beyond the RDA implications for optimizing health. Appl Physiol Nutr Metab 41: 565-572. [Crossref]

42. Eisenstein J, Roberts SB, Dallal G, Saltzman E (2002) High-protein weight-loss diets: are they safe and do they work? A review of the experimental and epidemiologic data Nutr Rev 60: 189-200. [Crossref]

43. Ritz P (1997) Moduler la part de protéines et de glucides: est-ce utile pour perdre du poids. Diabetes \& Obesite.

44. Da Silva MS, Rudkowska I (2014) Dairy products on metabolic health: current research and clinical implications. Maturitas 77: 221-228. [Crossref]

45. Stonehouse W, Wycherley T, Luscombe-Marsh N, Taylor P, Brinkworth G, et al. (2016) Dairy Intake Enhances Body Weight and Composition Changes during Energy Restriction in 18-50-Year-Old Adults-A Meta-Analysis of Randomized Controlled Trials. Nutrients 8: 394. [Crossref]

46. Abeyrathne ED, Lee HY, Ahn DU (2013) Egg white proteins and their potential use in food processing or as nutraceutical and pharmaceutical agents-a review. Poult Sci 92: 3292-3299. [Crossref]

47. Makki K, Froguel P, Wolowczuk I (2013) Adipose tissue in obesity-related inflammation and insulin resistance: cells, cytokines, and chemokines. ISRN Inflamm 2013: 139239. [Crossref]

48. Adabimohazab R, Garfinkel A, Milam EC, Frosch O, Mangone A, et al. (2016) Does inflammation mediate the association between obesity and insulin resistance? Inflammation 39: 994-1003. [Crossref]

49. Bosse JD, Dixon BM (2012) Dietary protein in weight management: a review proposing protein spread and change theories. Nutr Metab (Lond) 9: 81. [Crossref]

50. Simpson SJ, Raubenheimer D (2005) Obesity: the protein leverage hypothesis. Obes Rev 6: 133-142. [Crossref]

51. Johnston CS, Day CS, Swan PD (2002) Postprandial thermogenesis is increased $100 \%$ on a high-protein, low-fat diet versus a high-carbohydrate, low-fat diet in healthy, young women. J Am Coll Nutr 21: 55-61. [Crossref]

52. Jéquier E, Acheson K, Schutz Y (1987) Assessment of energy expenditure and fue utilization in man. Annu Rev Nutr 7: 187-208. [Crossref]

53. Ravussin E, Gautier JF: Déterminants et contrôle des dépenses énergétiques. Ann Endocrinol (Paris) 2002, 63 :96-105. [Crossref]
54. Porrini M, Santangelo A, Crovetti R, Riso P, Testolin G, et al. (1997) Weight, protein, fat, and timing of preloads affect food intake. Physiol Behav 62: 563-570. [Crossref]

55. Anderson GH, Moore SE (2004) Dietary proteins in the regulation of food intake and body weight in humans. J Nutr 134: 974S-9S. [Crossref]

56. Rolland-Cachera MF, Deheeger M, Akrout M, Bellisle F (1995) Influence of macronutrients on adiposity development: a follow up study of nutrition and growth from 10 months to 8 years of age. Int J Obes Relat Metab Disord 19: 573-578. [Crossref]

57. Trichopoulou A, Gnardellis C, Benetou V, Lagiou P, Bamia C, et al. (2002) Lipid, protein and carbohydrate intake in relation to body mass index. Eur J Clin Nutr 56: 37-43. [Crossref]

58. Hammond KA, Janes DN (1998) The effects of increased protein intake on kidney size and function. J Exp Biol 201: 2081-2090. [Crossref]

59. Linn T, Santosa B, Gronemeyer D, Aygen S, Scholz N, et al. (2000) Effect of long-term dietary protein intake on glucose metabolism in humans. Diabetologia 43: 1257-1265. [Crossref]

60. Skov AR, Toubro S, Bulow J, Krabbe K, Parving HH, et al. (1999) Changes in renal function during weight loss induced by high vs low-protein low-fat diets in overweight subjects. Int J Obes Relat Metab Disord 23: 1170-1177. [Crossref]

61. Woods LL (1993) Mechanisms of renal hemodynamic regulation in response to protein feeding. Kidney Int 44: 659-675. [Crossref]

62. Slag MF, Ahmad M, Gannon MC, Nuttall FQ (1981) Meal stimulation of cortisol secretion: a protein induced effect. Metabolism 30: 1104-1108. [Crossref]

63. Kerstetter JE, Mitnick ME, Gundberg CM, Caseria DM, Ellison AF, et al. (1999) Changes in bone turnover in young women consuming different levels of dietary protein. J Clin Endocrinol Metab 84: 1052-1055. [Crossref]

64. Licata AA, Bou E, Bartter FC, West F (1981) Acute effects of dietary protein on calcium metabolism in patients with osteoporosis. J Gerontol 36: 14-19. [Crossref]

65. Petzke KJ, Elsner A, Proll J, Thielecke F, Metges CC (2000) Long-term high protein intake does not increase oxidative stress in rats. J Nutr 130: 2889-2896. [Crossref]

66. Rao GN (1996) Influence of diet on tumors of hormonal tissues. Prog Clin Biol Res 394: 41-56. [Crossref]

67. Slentz CA, Aiken LB, Houmard JA, Bales CW, Johnson JL, et al. (2005) Inactivity, exercise, and visceral fat. STRRIDE: a randomized, controlled study of exercise intensity and amount. J Appl Physiol (1985) 99: 1613-1618. [Crossref]

68. Krauss RM, Eckel RH, Howard B, Appel LJ, Daniels SR, et al. (2000) AHA Dietary Guidelines: revision 2000: a statement for healthcare professionals from the Nutrition Committee of the American Heart Association. Circulation 102: 2284-2299. [Crossref]

69. Fidelix YL, Farias Júnior JC, Lofrano-Prado MC, Guerra RL, Cardel M, et al. (2015) Multidisciplinary intervention in obese adolescents: predictors of dropout. Einstein (Sao Paulo) 13: 388-394. [Croosref]

70. Moroshko I1, Brennan L, O'Brien P (2011) Predictors of dropout in weight los interventions: a systematic review of the literature. Obes Rev 12: 912-934. [Crossref]

Copyright: (C2018 Brun J. This is an open-access article distributed under the terms of the Creative Commons Attribution License, which permits unrestricted use, distribution, and reproduction in any medium, provided the original author and source are credited. 